\title{
Changes in body water and solids contents in native and crossbreed growing calves during winter and hot summer seasons of Egypt
}

\author{
Alsaied Alnaimy Habeeb (iD - Kamel Ahmed El-Masry - Ahmed Elsayed Gad
}

\author{
AA Habeeb (Corresponding author) - KA El-Masry - AE \\ Gad \\ Biological Applications Department, Radioisotopes \\ Applications Division, Nuclear Research Center, Atomic \\ Energy Authority, Inshas, P.O.13759, Cairo, Egypt.
}

Received: June 25, 2019 • Accepted: July 29, 2019 • Published Online: August 29, 2019

\begin{abstract}
The objective of this study is studying the effect of genetic crossing on body water and body solids in growing calves under winter or summer season in Egypt. Twenty calves including 10 native calves and $10 \mathrm{~F}_{1}$ calves ( $q$ Egyptian cow $\times \hat{O}$ Holstein) were used through two experiments. The first experiment was conducted during winter season on ten calves including 5 native and $5 \mathrm{~F}_{1}$ calves with average 5-6 months of age. The second experiment was conducted during summer season on another ten calves with the same age and body weight including 5 native calves and $5 \mathrm{~F}_{1}$ calves. Results showed that summer season induced significant decreases in live body weight (LBW) by $27.2 \mathrm{~kg}$ in native and by $32.9 \mathrm{~kg}$ in $F_{1}$ through 3 months and $F_{1}$ calves were better than native calves by $23.2 \mathrm{~kg}$ and $17.5 \mathrm{~kg}$ under winter and summer seasons, respectively. Total body water (TBW) as percentage of LBW values increased significantly and total body solids (TBS) as absolute values through three months decreased significantly by $6.9 \mathrm{~kg}$ in native calves and by $9.0 \mathrm{~kg}$ in $F_{1}$ calves due to exposure calves to summer season. Daily gain (BG) and daily solids gain (SG) decreased significantly due to exposure calves to summer season and $F_{1}$ calves were better than native calves in live BG as well as in SG. The best values in gain were in $F_{1}$ calves under winter condition and the worsted values were in native calves under summer season.
\end{abstract}

Keywords: body solids, body water, daily gain, heat stress, solids gain

\section{Introduction}

Information on the body water content of the live animals, especially under heat stress conditions of summer season of Egypt, is important for research whether the research involves nutrition, physiology, genetic, disease and meat production. Body weight alone provides a poor index of the metabolically active tissue or the mass of tissue available for meat. Live body weight (LBW) including total solids and total body water. Therefore, LBW of animals is a misleading index of growth performance, since it may be due to the increase in water retention and not to the increase in body protein and fat. In other words, a unit of LBW in one animal may be due to the increase in body water at the expense of body tissue loss, while in the other animal, may be due to the increase in body solids (Kamal and Habeeb 1984). In addition, water retention is known to vary considerably between animals during growth due to difference in the rate of accumulation of the less hydrated, fat, collegen and fibrous in replacement of the more hydrated functioning protoplasmic mass and to the age difference in response to nutritional and climatic factors (Habeeb et al 1992). Using Antipyrine dilution technique as indirect methods of estimating body water, body solids (body weight - body water), body composition and detection the heat adaptability coefficient in live animals can provide repeated estimates for the same animal besides easily, accurate and quickly technique and more reliable whereas slaughter and chemical analysis obviously can only be done once (Habeeb et al 2014).

The exotic bull breeds are used for crossbreeding purposes to take advantage of potential heterotic effects (Mostageer et al 1990, Olson 2011). High productive imported animals like Brown Swiss or Holstein Friesian can be crossed with native cattle because such practice may allow the Egyptian native cattle producer to take advantage of appropriate combinations of the superior traits of Brown Swiss or Holstein Friesian breeds to yields heterosis which often referred to as hybrid vigor (Marai and Habeeb 2010a).

Farm animals are reared under hot summer season in Egypt for almost 8 months of the year. Summer is characterized by high ambient temperature, intense solar radiation and high relative humidity. Therefore farm animals exposed to severe heat stress and become uncomfortable and the productive traits of animals are deleteriously affected by 
the disturbance in the normal water balance (Habeeb et al 1992).

Little information is available on body water and body solids in each of native cattle calves and F1 calves produced from crossing between $\delta$ Holstein and $q$ Native cattle. Effect of genetic crossing on body water and body solids contents in growing calves under winter and summer seasons is the objective of this study.

\section{Materials and Methods}

\section{Location and ethics}

The experimental wok was carried out in bovine farm project, Experimental Farms Project, Biological Application Department, Radioisotopes Applications Division, Nuclear Research Centre, Atomic Energy Authority, Inshas, Cairo, Egypt (latitude $31^{\circ} 12^{\prime} \mathrm{N}$ to $22^{\circ} 2^{\prime} \mathrm{N}$, longitude $25^{\circ} 53^{\prime} \mathrm{E}$ to $35^{\circ} 53^{\prime}$ E) during the year of 2017.
Experimental animals were cared using husbandry guidelines derived from Egyptian Atomic Energy Authority standard operating procedures. This work was reviewed and approved by the Animal Care and Welfare Committee of Egyptian Atomic Energy Authority. These ethics contain relevant information on the Endeavour to reduce animal suffering and adherence to best practices in veterinary care according to the International Council for Laboratory Animal Science guidelines.

\section{Animals and feeding}

The study was carried out on twenty calves after weaning with average 5-6 months of age and average live body weight of $140 \mathrm{~kg}$ including 10 Egyptian bovine calves and $10 \mathrm{~F}_{1}$ calves ( $q$ Egyptian cows $\mathrm{x} \hat{\jmath}$ Holstein) were used. Animals were fed the ration consisted of concentrate feed mixture (CFM) and rice straw (RS). The ingredients of the CFM and chemical composition of the feed stuffs used in the feeding of the calves are shown in Table 1.

Table 1 Ingredients of the concentrate feed mixture and chemical composition of the feed stuffs used in the feeding of the calves during the experimental period.

\begin{tabular}{|c|c|c|}
\hline Items & Concentrate feed mixture & Rice straw \\
\hline \multicolumn{3}{|l|}{ Ingredients of the concentrate $(\%)$ : } \\
\hline Crushed yellow maize $\%$ & 40.00 & \\
\hline Wheat bran \% & 25.50 & \\
\hline Soybean meal \% & 7.00 & \\
\hline Undecorticated cotton seed meal & 25.00 & \\
\hline Dicalcium phosphate $\%$ & 1.00 & \\
\hline Sodium chloride $\%$ & 1.00 & \\
\hline Mineral mixture \%* & 0.50 & \\
\hline Vitamin $\mathrm{AD}_{3} \mathrm{E} \%$ & 0.50 & \\
\hline \multicolumn{3}{|c|}{ Analysis of chemical composition of the feed stuffs (on DM basis)**, \%: } \\
\hline Dry matter & 89.81 & 92.30 \\
\hline Organic matter & 94.00 & 83.52 \\
\hline Crude protein & 15.68 & 3.20 \\
\hline Crude fiber & 8.50 & 32.70 \\
\hline Ether extract & 2.67 & 1.80 \\
\hline Nitrogen-free extract & 67.15 & 44.60 \\
\hline Ash & 6.00 & 17.70 \\
\hline \multicolumn{3}{|l|}{ Calculated Nutritive values of the feed stuffs: } \\
\hline Net energy (MJ/kg DM) & 4.00 & 1.60 \\
\hline Total digestible nutrients (\%) & 60.82 & 30.00 \\
\hline Digestible crude protein (g/kg DM) & 115.0 & 0.00 \\
\hline Starch equivalent & 0.50 & 0.20 \\
\hline
\end{tabular}

* Vitamin and Mineral premix each 2.5 kg consists of: Vit A 12000, 000 IU; Vit $D_{3}, 2000,000$ IU; Vit. E. 10g; Vit k; 2 g; Vit B 1000 $\mathrm{mg}$; Vit $\mathrm{B}_{2}, 49 \mathrm{~g}$; Vit $\mathrm{B}_{6}, 105 \mathrm{~g}$; Vit $\mathrm{B}_{12}, 10 \mathrm{mg}$; Pantothenic acid, $10 \mathrm{~g}$; Niacin, $20 \mathrm{~g}$, Folic acid, $1000 \mathrm{mg}$; Biotin, $50 \mathrm{~g}$; Choline Chloride, $500 \mathrm{mg}, \mathrm{Fe}, 30 \mathrm{~g}$; $\mathrm{Mn}, 40 \mathrm{~g} ; \mathrm{Cu}, 3 \mathrm{~g} ; \mathrm{Co}, 200 \mathrm{mg} ; \mathrm{Si}, 100 \mathrm{mg}$ and $\mathrm{Zn}, 45 \mathrm{~g}$.

** According to AOAC (1990). 


\section{Experimental design and environmental conditions}

Twenty healthy calves after weaning including 10 native calves and $10 \mathrm{~F}_{1}$ calves ( $q$ Egyptian cow x $\hat{\jmath}$ Holstein) were used in two experiments. The $1^{\text {st }}$ experiment was conducted during winter season on ten calves including 5 native calves and $5 \mathrm{~F}_{1}$ calves with average 5-6 months of age and average live body weight of $140 \mathrm{~kg}$. The $1^{\text {st }}$ experiment lasted three months during winter season 2017, since the ambient temperature (AT) and relative humidity (RH \%) values were $20.0 \pm 0.76{ }^{\circ} \mathrm{C}$ and $69.9 \pm 0.30 \%$, respectively. The $2^{\text {nd }}$ experiment was on another ten calves with the same age and body weight including 5 native calves and $5 \mathrm{~F}_{1}$ calves. The $2^{\text {nd }}$ experiment lasted three months conducted during summer season 2017, since the ambient temperature (AT) and RH\% were $37.4 \pm 0.32^{\circ} \mathrm{C}$ and $50.2 \pm 0.73 \%$, respectively (Table 2 ).

Table 2 Monthly averages of ambient temperature (AT, $\left.{ }^{\circ} \mathrm{C}\right)$, relative humidity $(\mathrm{RH} \%)$ and temperature humidity index (THI) values at midday during the two experiments.

\begin{tabular}{|c|c|c|c|c|}
\hline $\begin{array}{c}\text { Two } \\
\text { experiments }\end{array}$ & $\begin{array}{c}\text { Experimental } \\
\text { months }\end{array}$ & $\begin{array}{c}\text { Ambient temperature } \\
\left(\mathrm{AT},{ }^{\circ} \mathrm{C}\right)\end{array}$ & $\begin{array}{c}\text { Relative humidity } \\
\text { (RH, \%) }\end{array}$ & $\begin{array}{l}\text { Temperature humidity } \\
\text { index (THI) }\end{array}$ \\
\hline \multirow{4}{*}{$\begin{array}{c}1^{\text {st }} \text { experiment } \\
\text { (Winter) }\end{array}$} & January & $19.5 \pm 0.29$ & $69.5 \pm 1.5$ & 65.57 \\
\hline & February & $19.0 \pm 0.41$ & $69.8 \pm 2.1$ & 64.84 \\
\hline & March & $21.5 \pm 0.29$ & $70.5 \pm 2.2$ & 68.64 \\
\hline & Overall & $20.0 \pm 0.76$ & $69.9 \pm 0.30$ & 66.35 \\
\hline \multirow{4}{*}{$\begin{array}{c}2^{\text {nd }} \text { experiment } \\
\text { (Summer) }\end{array}$} & June & $36.8 \pm 1.4$ & $51.5 \pm 0.44$ & 87.51 \\
\hline & July & $37.5 \pm 1.8$ & $50.0 \pm 0.58$ & 88.09 \\
\hline & August & $37.9 \pm 1.5$ & $49.0 \pm 0.48$ & 88.36 \\
\hline & Overall & $37.4 \pm 0.32$ & $50.2 \pm 0.73$ & 87.99 \\
\hline
\end{tabular}

Each value from air temperature and relative humidity was the average of 4 numbers recorded weekly at 13:00.

The THI was calculated as following $\mathrm{THI}=(1.8 * \mathrm{AT}+$ $32)-[(0.55-0.0055 * \mathrm{RH}) \times(1.8 * \mathrm{AT}-26)]$, where AT $=$ air temperature $\left({ }^{\circ} \mathrm{C}\right)$, and $\mathrm{RH}=$ relative humidity $(\%)$ according to Kendall and Webster (2009) who reported that THI thresholds for heat stress in cattle as following: comfort (THI $<68)$, mild discomfort $(68<\mathrm{THI}<72)$, discomfort $(72<\mathrm{THI}$ $<75)$, alert $(75<\mathrm{THI}<79)$, danger $(79<\mathrm{THI}<84)$, and emergency (THI > 84). THI values indicate that absence of heat stress (comfort) during winter and very severe heat stress (emergency) during summer seasons of Egypt.

\section{Estimation of gain}

The animals were weighed monthly to the nearest $1 \mathrm{~kg}$ before the morning feed. Each calf was weighted monthly during each of winter and summer seasons to obtain live body weight (LBW). Daily body weight gain values were estimated by dividing total live body weight gain $(\mathrm{kg})$ during each season (final LBW-initial LBW) by 90 days.

\section{Animal housing and management}

The experimental calves were left loose day and night during both winter and summer seasons in one separate soilfloored yard $(20 \times 40 \mathrm{~m})$ surrounded with wire fence $(1.5 \mathrm{~m}$ height). One-third of the surface area of the yard was covered with concrete shading roof in the middle ( $3.5 \mathrm{~m}$ height) with natural ventilation. The yard was provided also with troughs and source of tab fresh drinking water to be available automatically at all time to the animals.

Estimation of total body water (TBW) using Antipyrine (ANP)

Each animal was injected in the left jugular vein with antypyrine (ANP) at the rate of $1 \mathrm{~g}$ per $100 \mathrm{~kg}$ live weight in both the beginning and the end of winter and summer seasons to determined total body water (TBW) according to Habeeb (2019). After 1 hour from injection of ANP to be distributed in all animal body, blood samples were withdrawn from write jugular vein for TBW and consequently total body solids (TBS) by subtracting TBW from live body weight. Solids body weight gain was estimated by dividing TBS $(\mathrm{kg})$ by 90 days. Chemical reagents required for ANP estimation are zinc reagent solution $(10 \%)$, sodium hydroxide $(0.75 \mathrm{~N})$, sodium nitrite $(0.2 \%)$ and $\mathrm{H}_{2} \mathrm{SO}_{4}$ acid with different normality $(6 \mathrm{~N}$, $4 \mathrm{~N}$ and $0.07 \mathrm{~N}$ ). Precipitation of plasma proteins in plasma samples was carried out using zinc sulphate and centrifuged at the rate of $2000 \mathrm{rpm}$ for 20 minutes. ANP concentration in supernatant was estimated by computerized spectrophotometer at $350 \mathrm{UV}$. TBW, $\mathrm{ml}$ in animals was determined by dividing concentration of ANP injected $(\mu)$ / concentration of ANP in plasma sample $(\mu / \mathrm{ml})$.

To determine percentage of heterosis, divide the amount of heterosis by the native average; then multiply by $100 \%$; this yields a heterosis value for the $F_{1}$ calves (Olson 2011). 


\section{Statistical analysis}

Data were statistically analyzed by two-way analysis of variance using the General Linear Model Procedure of the SAS software (SAS 2002). The model used is: $\mathrm{Yij}=\mu+\mathrm{S}_{\mathrm{i}}+$ $\mathrm{T}_{\mathrm{j}}+(\mathrm{ST})_{\mathrm{ij}}+\mathrm{e}_{\mathrm{ijk}}$ where: $\mu=$ the overall mean; $\mathrm{S}_{\mathrm{i}}=$ the fixed effect of season $(1=$ winter and $2=$ summer $) ; T_{j}=$ the fixed effect of type of calves $\left(1=\right.$ native and $\left.2=\mathrm{F}_{1}\right)$; $(\mathrm{ST})_{\mathrm{ij}}=$ the interaction between the season and type of calves and $\mathrm{e}_{\mathrm{ijk}}=$ random error. Significance of the difference in the results was verified by Duncan's new multiple ranges test (Duncan 1955). The percentage change due to summer heat stress (HS) as compared to mild climate of winter season (MC) was calculated as (MC- HS) x100/MC. The percentage change due to crossing $(\mathrm{C})$ in $\mathrm{F}_{1}$ as compared to native $(\mathrm{N})$ was calculated as $(\mathrm{C}-\mathrm{N}) \times 100 / \mathrm{N}$.

\section{Results}

Changes due to heat stress of summer season on $L B W$, $T B W \%$ and $T B S$

LBW of native calves increased by 52.7 during winter and $25.5 \mathrm{~kg}$ during summer seasons, indicating that heat stress conditions induced a significant decrease in LBW of native calves in 90 days by $27.2 \mathrm{~kg}$ (51.4\%). In $\mathrm{F}_{1}$ calves, LBW through 3 months increased 75.9 during winter and $43.0 \mathrm{~kg}$ during summer seasons as shown in Table (3).

Table 3 Changes in live body weight (LBW), total body water (TBW) and total body solids (TBS) in native and F1 calves due to exposed calves to winter or summer season in Egypt.

\begin{tabular}{|c|c|c|c|c|}
\hline Changes in Parameters & Type of calves & $\begin{array}{l}\text { Winter } \\
\text { season }\end{array}$ & $\begin{array}{l}\text { Summer } \\
\text { season }\end{array}$ & $\begin{array}{c}\text { Change due to heat stress } \\
\text { of summer season }\end{array}$ \\
\hline \multirow[t]{2}{*}{ Change in LBW, $\mathrm{kg}$} & Native calves & +52.7 & +25.5 & $\begin{array}{l}-27.20 \mathrm{~kg} \\
(51.4 \%)^{* *}\end{array}$ \\
\hline & $F_{1}$ calves & +75.9 & +43.0 & $\begin{array}{l}-32.90 \mathrm{~kg} \\
(43.3 \%)^{* *}\end{array}$ \\
\hline Change in TBW as percentage & Native calves & 65.1 & 68.1 & $+3.00^{* *}$ \\
\hline of LBW & $\mathrm{F}_{1}$ calves & 66.1 & 70.0 & $+3.90^{* *}$ \\
\hline \multirow[t]{2}{*}{$\begin{array}{c}\text { Change in TBS, } \mathrm{kg} \text { as absolute } \\
\text { value }\end{array}$} & Native calves & +19.4 & +12.5 & $\begin{array}{l}-6.90 \mathrm{~kg} \\
(35.6 \%)^{* *}\end{array}$ \\
\hline & $\mathrm{F}_{1}$ calves & +28.7 & +19.7 & $\begin{array}{l}-9.00 \mathrm{~kg} \\
(31.4 \%)^{* *}\end{array}$ \\
\hline Change in TBS, $\mathrm{kg}$ as & Native calves & 34.9 & 31.9 & $-3.00^{* *}$ \\
\hline percentage of LBW & $\mathrm{F}_{1}$ calves & 33.9 & 30.0 & $-3.90^{* *}$ \\
\hline
\end{tabular}

This result means that summer season induced significant decrease in LBW of $\mathrm{F}_{1}$ calves in 90 days by 32.9 $\mathrm{kg}(43.3 \%)$. When comparing between the two breeds, the result of LBW showed that $\mathrm{F}_{1}$ calves were better than native calves by $23.2 \mathrm{~kg}$ (75.9 vs.52.7) and $17.5 \mathrm{~kg}$ (43.0 vs. 25.5) under both winter and summer seasons, respectively. TBW as percentage of LBW values increased significantly due to exposure either native or $F_{1}$ calves due to summer heat stress conditions. TBW\% value in native was 65.1 under winter climate and increased to 68.1 under summer season. In $F_{1}$ calves TBW\% value was 66.1 under winter climate and increased to 70.0 under summer season as shown in Table 3.

In native calves, total body solids (TBS) as absolute value in kilograms increased significantly by $19.4 \mathrm{~kg}$ during 90 days of winter season and $12.5 \mathrm{~kg}$ during 90 days of summer season, indicating that heat stress conditions of summer season induced significant decrease in TBS by $6.9 \mathrm{~kg}$. In $F_{1}$ calves, TBS as absolute value as $\mathrm{kg}$ increased significantly during 90 days by 28.7 and $19.7 \mathrm{~kg}$ in winter and in summer seasons, respectively. This result means that heat stress conditions of summer season induced significant decrease in TBS of F1 calves by $9.0 \mathrm{~kg}$. TBS as percentage of LBW values decreased significantly due to exposure either native or $\mathrm{F}_{1}$ calves to summer heat stress conditions. TBS\% value in native was $34.9 \%$ under winter climate and decreased to $31.9 \%$ under summer season. In $\mathrm{F}_{1}$ calves $\mathrm{TBS} \%$ value was $33.9 \%$ under winter climate and decreased to $30.0 \%$ under summer season. When comparing between the two breeds, the result showed that $F_{1}$ calves were better than native calves by $9.3 \mathrm{~kg}$ (28.7 vs.19.4) and $7.2 \mathrm{~kg}$ (19.7 vs. 12.5) under both winter and summer seasons, respectively as shown in Table 3. 
Changes due to heat stress of summer season on live and solids gain

Heat stress conditions of summer season induced highly significant reduction in live total body weight gain of calves by $30.0 \mathrm{~kg}$ through 3 months at the rate of $333.9 \mathrm{~g}$ daily when compared to mild climate conditions of winter season. The percentage decrease due to heat stress reached to more than $45 \%$ without consideration of calve type. When expressed total gain as solids, the results showed that the stressful condition of hot summer conditions induced significant reduction in total solids gain in claves by $8.0 \mathrm{~kg}$ in 90 days at the rate of $88.4 \mathrm{~g}$ daily when compared to absence of heat stress during winter season and the percentage decrease due to heat stress reached to more than $33 \%$ without consideration of calve type as shown in Table 4.

When comparing between the two breeds, the result showed that $F_{1}$ calves were better than native calves in live total gain by $20.4 \mathrm{~kg}$ with daily of $226.1 \mathrm{~g}$ with superiority of $52 \%$. The same trend, $\mathrm{F}_{1}$ calves were better than native calves in total solids gain by $8.2 \mathrm{~kg}$ at the rate of $91.6 \mathrm{~g}$ daily with best more than $50 \%$. Data concerning the interaction between seasons and type of calves shows that the best values in each of total and daily BWG either expressed as a live or a solids were in F1 calves under winter conditions (843.3 $\mathrm{g}$ and 318.9 $\mathrm{g}$ for live and solids, respectively) and the worsted values were in native calves during summer season (283.3 $\mathrm{g}$ and $138.9 \mathrm{~g}$ for live and solids, respectively) as shown in Table 4.

Table 4 Changes in total and daily live and solids gain in native and F1 calves due to exposed to winter or summer season in Egypt.

\begin{tabular}{|c|c|c|c|c|}
\hline \multirow[t]{2}{*}{ Factors affect } & \multicolumn{2}{|c|}{ Live body weight gain } & \multicolumn{2}{|c|}{ Solids body weight gain } \\
\hline & Total gain (kg/3 months) & Daily gain (g/day) & Total gain (kg/3months) & Daily gain (g/ day) \\
\hline \multicolumn{5}{|l|}{ Seasons } \\
\hline Winter & $64.3^{\mathrm{a}} \pm 1.5$ & $714.5^{\mathrm{a}} \pm 18.1$ & $24.1^{\mathrm{a}} \pm 0.7$ & $267.3^{\mathrm{a}} \pm 7.8$ \\
\hline Summer & $34.3^{\mathrm{b}} \pm 1.7$ & $380.6^{\mathrm{b}} \pm 18.6$ & $16.1^{\mathrm{b}} \pm 0.8$ & $178.9^{\mathrm{b}} \pm 7.5$ \\
\hline \multirow[t]{2}{*}{ Decrease due to hot summer } & $30.0 \mathrm{~kg}$ & $333.9 \mathrm{~g} /$ day & $8.0 \mathrm{~kg}$ & $88.4 \mathrm{~g} /$ day \\
\hline & $(-46.7 \%)^{* *}$ & $(-44.7 \%)^{* *}$ & $(-33.2 \%)^{* *}$ & $(-33.1 \%)^{* *}$ \\
\hline \multicolumn{5}{|l|}{ Type of calves } \\
\hline Native calves & $39.1^{\mathrm{b}} \pm 1.8$ & $434.5^{\mathrm{b}} \pm 15.1$ & $16.0^{\mathrm{b}} \pm 0.6$ & $177.3^{\mathrm{b}} \pm 8.8$ \\
\hline $\mathrm{F}_{1}$ & $59.5^{\mathrm{a}} \pm 1.5$ & $660.6^{\mathrm{a}} \pm 15.6$ & $24.2^{\mathrm{b}} \pm 0.7$ & $268.9^{\mathrm{a}} \pm 9.8$ \\
\hline \multirow[t]{2}{*}{ Increase in F1 vs. native } & $20.4 \mathrm{~kg}$ & $226.1 \mathrm{~g} /$ day & $8.2 \mathrm{~kg}$ & $91.6 \mathrm{~g} /$ day \\
\hline & $(+52.2 \%)^{* *}$ & $(+52.0 \%)^{* *}$ & $(+51.3 \%)^{* *}$ & $(+51.7 \%)^{* *}$ \\
\hline \multicolumn{5}{|c|}{ Interactions between season and type of calves } \\
\hline \multicolumn{5}{|l|}{ Winter } \\
\hline Native calves & $52.7^{b} \pm 3.2$ & $585.6^{\mathrm{b}} \pm 32.9$ & $19.4^{\mathrm{b}} \pm 0.9$ & $215.6^{\mathrm{b}} \pm 10.3$ \\
\hline $\mathrm{F}_{1}$ & $75.9^{\mathrm{a}} \pm 0.64$ & $843.3^{\mathrm{a}} \pm 7.1$ & $28.7^{\mathrm{a}} \pm 0.8$ & $318.9^{\mathrm{a}} \pm 8.8$ \\
\hline \multirow[t]{2}{*}{ Increase in F1 vs. native } & $23.2 \mathrm{~kg}$ & 257.7 g/day & $9.3 \mathrm{~kg}$ & $103.3 \mathrm{~g} /$ day \\
\hline & $(+44.0 \%)^{* *}$ & $(+44.0 \%)^{* *}$ & $(+47.9 \%)^{* *}$ & $(+47.9 \%)^{* *}$ \\
\hline \multicolumn{5}{|l|}{ Summer } \\
\hline Native calves & $25.5^{\mathrm{d}} \pm 0.8$ & $283.3^{\mathrm{d}} \pm 9.3$ & $12.5^{\mathrm{c}} \pm 0.3$ & $138.9^{c} \pm 3.7$ \\
\hline $\mathrm{F}_{1}$ & $43.0^{c} \pm 3.5$ & $477.8^{c} \pm 38.7$ & $19.7^{\mathrm{b}} \pm 1.5$ & $218.9^{\mathrm{b}} \pm 16.9$ \\
\hline \multirow[t]{2}{*}{ Increase in F1 vs. native } & $17.5 \mathrm{~kg}$ & $194.5 \mathrm{~g} /$ day & $7.2 \mathrm{~kg}$ & $80.0 \mathrm{~g} /$ day \\
\hline & $(+68.6 \%)^{* *}$ & $(+68.7 \%)^{* *}$ & $(+57.6 \%)^{* *}$ & $(+57.6 \%)^{* *}$ \\
\hline
\end{tabular}

The percentage change due to summer heat stress (HS) as compared to mild climate of winter season (MC) was calculated as (MC- HS) x100 / MC. The percentage change due to type of calves, F1 (C) as compared to native (N) was calculated as $(\mathrm{C}-\mathrm{N}) \mathrm{x} 100 / \mathrm{N}$.

a,b,c Different letters in each column of interaction indicate significant differences at $<0.5$ and $a>b>c>d$.

$* *$ Significant at $<.001$ 


\section{Discussion}

Growth traits of calves are deleteriously affected by heat stress conditions of summer season and calves LBW improved significantly in $F_{1}$ ( $1 / 2$ Brown Swiss $x 1 / 2$ Native cows) calves due to crossing process under both winter and summer seasons (Habeeb et al 2014 and 2017). Holstein crossed with local breeds in the tropics and subtropics perform better than the purebred Holstein and were also resistant to heat stress (Pastsart et al 2006 and Molee et al 2011). The depression in LBW in calves under summer season is due to that animals suffer extremely by severe stress conditions which associated in disturbance in the normal physiological balance and biological functions (Marai and Habeeb 2010b). In addition, high environmental temperature during hot summer season stimulates the peripheral thermal receptors to transmit suppressive nerve impulses to the appetite centre in the hypothalamus causing the decrease in dry matter intake (DMI). Thus, fewer substrates become available for enzymatic activities, hormone synthesis and heat production and consequently LBW of calves are decreased (Habeeb et al 1992). The feed intake of cows at $40{ }^{\circ} \mathrm{C}$ is reduced by $20-40 \%$ compared with cows in thermoneutral environment. In addition, during heat stress, DMI, gut motility, rumination, ruminal contractions are reduced due to depress animal appetite by having a direct negative effect on appetite centre of the hypothalamus (Yasothai 2014). Increase in environmental temperature has a direct negative effect on appetite center of the hypothalamus to decreases feed intake. Feed intake begins to decline at air temperatures of $25-26{ }^{\circ} \mathrm{C}$ in lactating cows and reduces more rapidly above $30{ }^{\circ} \mathrm{C}$ in temperate climatic condition and at $40{ }^{\circ} \mathrm{C}$ it may decline by as much as $40 \%$ (Rhoads et al 2013) or $8-10 \%$ in buffalo heifers (Hooda and Singh 2010). Reducing feed intake is a way to decrease heat production in warm environments as the heat increment of feeding is an important source of heat production in ruminants (Kadzere et al 2002). As results, animals experience a stage of negative energy balance (NEB), consequently, body weight and body condition score goes down (Garner et al 2017).

TBW as percentage of LBW values increased significantly either in native or in $\mathrm{F}_{1}$ calves due to exposure to summer heat stress conditions. The water requirements are determined by the amount needed to give the proper osmotic concentration to body fluids and to compensate for total water loss. To maintain TBW content at a relatively constant level it is important that a continuous supply of water must be provided. In a steady state (comfortable conditions), water intake (including free water, feed water and metabolic water, which is derived from oxidation of fat, carbohydrates and proteins) must balance water output (including urine, sweating, skin vaporization and respiratory vaporization) as declared previously by Habeeb et al (1992). Under hot climate, water plays a major role in heat dissipation through evaporative cooling including sweating (skin vaporization), and respiratory vaporization and thermal conduction between consumed water and both of body core and excreted water through urine, feces, milk, salivation, tears and nasal tract secretions but vaporization at high temperature is considered the main route of heat dissipation (Kamal et al 1984). The increase in TBW in calves during summer season is due to that the increase in water vaporization, which stimulates the peripheral thermal receptors to transmit suppressive nerve impulses to the thirst center in the hypothalamus causing the increase in water consumption (Habeeb et al 2017). Thermal stress increases water metabolism and maximum water intake during the hot period was at least doubled from the control period, from 4.8 to $9.8 \%$ in Bos taurus and 3.8 to $9.3 \%$ in Bos indicus. This is mainly due to lower plasma concentrations of metabolic hormones such as thyroxin, growth hormone and corticoids (Farooq et al 2010; Yasothai 2014).

Heat stress conditions of summer season induced significant decrease in TBS as absolute value in kilograms through 3 months by $6.9 \mathrm{~kg}$ in native calves and by $9.0 \mathrm{~kg}$ in $\mathrm{F}_{1}$ calves (Table 3 ). In growing buffaloes, TBS were similarly lower at $32{ }^{\circ} \mathrm{C}$ and $50 \% \mathrm{RH}$ than at $18{ }^{\circ} \mathrm{C}$ and $50 \% \mathrm{RH}(100$ and $124 \mathrm{~kg}$, respectively) (Kamal et al 1972). In Holstein calves, the heat caused a $15 \%$ decrease significantly in TBS (Kamal and Johnson 1971). In buffaloes and Friesians, the TBS decreased by $11.42 \%$ at each level of temperature, when the ambient temperature increased from $16{ }^{\circ} \mathrm{C}, 50 \% \mathrm{RH}$ to 32 ${ }^{\circ} \mathrm{C}, 50 \% \mathrm{RH}$, constantly for one week, in the climatic chamber (Kamal and Seif 1969). In Friesian calves, the average body solid content decreased by $16 \%$ with the increase in ambient temperature in the climatic chamber and concluded that the destruction of body tissues as a result of heat exposure is considered to be a serious stage of heat stress in animals Kamal (1982). Heat stress induced significant decrease in TBS in both male and female Friesian calves (Kamal and Habeeb 1999).

Total live and total solids gain values are decreased by 30.0 and $8.0 \mathrm{~kg}$ through 3 months at the rate of 333.9 and 88.4 $\mathrm{g}$ daily due to exposure the experimental calves to hot summer season. $F_{1}$ calves were better than native calves in live BWG by $20.4 \mathrm{~kg}$ through three months with daily of $226.1 \mathrm{~g}$ and in solids BWG by $8.2 \mathrm{~kg}$ through three months at the rate of 91.6 $\mathrm{g}$ daily.

Heat stress conditions induced significant reduction in DBWG of buffalo calves by 22.6 and $16.5 \%$, respectively, when compared to mild climate conditions $\left(18.0^{\circ} \mathrm{C}\right)$ (Habeeb et al 2007). Stressful condition of hot climatic conditions induced significant reduction in DBWG of bovine claves and the percentage heat induced change were ranged between 3.2 to $48.4 \%$ with average of $25.5 \%$ (Habeeb et al 2009). The heat stress induced a highly significant decline in DBWG in Friesian calves by 14.0, 29.0 and 22.0\% during May, June and July months, respectively (Habeeb et al 2011). The heat stress 
conditions of summer season induced significant decline in DBWG of buffalo calves by $18.1,17.41$ and $8.65 \%$ during $1^{\text {st }}$, $2^{\text {nd }}$ and $3^{\text {rd }}$ months of summer season, respectively (Habeeb et al 2012). Calves body weight gains (either live or solids) improved significantly in F1 ( $1 / 2$ Brown Swiss $x \quad 1 / 2$ Native cows) calves due to crossing process under both winter and summer seasons (Habeeb et al 2017). The crossbred calves (50\% Brown Swiss:50\% native Baladi) under hot summer climate in Egypt showed significantly higher daily feed intake and body gain as well as a better feed conversion ratio compared with native Baladi calves and concluded that the crossbred calves exhibit a better growth performance, economic efficiency and stable physiological responses compared with the native calves under hot environment in the summer season (Ali and El-Tarabany 2019).

The decrease in calves body weight gains (either live or solids) during summer season may be due to a decrease in feed consumption, dehydration of animals, tissue catabolism and to the low metabolically energy left for growth, since more energy is consumed by the increase in respiratory frequency that occurs in hot ambient temperature (Marai and Habeeb 2010ab). DMI was significantly lower during summer than those during winter (Shwartz et al 2009). Dry matter intake (DMI) was significantly lower during summer than those during winter and the percentage decrease was 22.5 in native bovine calves and was 24.8 in $F_{1}\left(1 / 2\right.$ brown Swiss $x \frac{1}{2}$ Native cows) calves (Habeeb et al 2017). Feed conversion values as $\mathrm{kg} \mathrm{DMI} / \mathrm{kg}$ gain were $7.35 \pm 0.32$ and $10.97 \pm 0.22$ in bovine calves and were $5.03 \pm 0.12$ and $6.67 \pm 0.25$ in $F 1$ ( $1 / 2$ brown Swiss $x$ 1/2 Native cows) calves under winter and hot summer seasons, respectively. FC was significantly higher during summer than those during winter by $3.62 \mathrm{~kg}$ DMI $/ \mathrm{kg}$ gain in native bovine calves and by $1.64 \mathrm{~kg} \mathrm{DMI} / \mathrm{kg}$ gain in calves. The percentage increase due to hot summer season was 49.25 in native bovine calves and was 32.6 in $\mathrm{F} 1$ calves compared to winter season (Habeeb et al 2017). In this measure, a higher number of FC indicates less efficiency.

Animal decrease DMI in an attempted to create less metabolic heat, as the heat increment of feeding, especially in ruminants is a large portion of whole body heat production (Kadzere et al 2002). Decrease in DMI cause the decrease in the substrates and hormones which inhibit the enzymatic activities and decrease the metabolism and consequently impair DBWG. In addition, exposure animals to hot summer environment can affect digestibility of feed stuffs (Bernabucci et al 1999). The decrease in thyroid hormonal levels and the increase in cortisol hormone during summer season may also contribute in TBS losses and in depression of gain either lives or solids during summer season (Habeeb et al 2017). The superiority of F1 in body weight gains (either live or solids) than native calves may be due to superiority in feed intake during summer season. DMI and feed conversion values were improved significantly in F1 ( $1 / 2$ Brown Swiss x $1 / 2$ Native cows) calves due to crossing process under each of winter and summer season (Habeeb et al 2017). DMI was higher in all the crosses than in purebred Brahman animals and consequently fed conversion improved due to crossing (Norris et al 2002).

\section{Conclusions}

Heat stress conditions of summer season had adversely affects on growth traits of both native and $F_{1}$ calves. $F_{1}$ calves were better than native calves in live and solids BWG more than $50 \%$. Moreover, the best body gain was in crossing calves under both winter and summer seasons.

\section{References}

Ali MA, El-Tarabany MS (2019) Blood biochemical indices, growth performance and economic efficiency of growing native Baladi and crossbred calves under hot summer conditions. Biological Rhythm Research. DOI: 10.1080/09291016. 2018.1478620

AOAC (1990) Official methods of analysis. $5^{\text {th }}$ Edition, Association of Official Analysis Chemists, Washington, DC, USA.

Bernabucci U, Bani P, Ronchi B, Lacetera N, Nardone A (1999) Influence of short- and long - term exposure to a hot environment on Rumen Passage rate and diet digestibility by Friesian heifers. Journal of Dairy Science 82:967-973.

Duncan DB (1955) Multiple Range and multiple F- test. Biometrics, 11: $1-42$.

Farooq U, Samad HA, Shehzad F, Qayyum A (2010) Physiological responses of cattle to heat stress. World Applied Sciences Journal 8:38-43.

Garner JB, Douglas A, Williams A, Wales A, Marett A, DiGiacomo B, Leury B, Hayes C D (2017) Responses of dairy cows to short-term heat stress in controlled-climate chambers. Animal Production Science 57:1233-1241

Habeeb AAM, El-Masry KA, Teama FEI, Gad AE (2009) The Role of cyclic Guanosine Mono-Phosphate (cGMP) and heat shock proteins in heat stressed cattle. Egyptian Journal of Applied Sciences $24: 32-56$

Habeeb AAM (2019) Simple methods to estimate total body water in live animals using Antipyrine with detection of heat adaptability. Journal of Animal Research and Nutrition. DOI: 10.21767/25725459.100051

Habeeb AAM, Fatma EI Teama, Osman SF (2007) Detection of heat adaptability using Heat shock proteins and some hormones in Egyptian buffalo calves. Egyptian Journal of Applied Sciences 22:28-53.

Habeeb AAM, Gad AE, El-Tarabany AA (2011) Effect of two climatic conditions and types of feeding on body weight gain and some physiological and biochemical parameters in crossing calves. Zagazig Veterinary Journal 39:34-48.

Habeeb AAM, Gad AE, El-Tarabany AA (2012) Effect of hot climatic conditions with different types of housing on productive efficiency and physiological changes in buffalo calves. Isotope and Radiation Research 44:109-126.

Habeeb AAM, El-Masry KAM, Atta MAA (2014) Growth Traits of Purebred and Crossbred Bovine Calves During Winter and Summer 
Seasons. $4^{\text {th }}$ International Conference on Radiation Sciences and Applications, Taba, Egypt: 1:10.

Habeeb AAM, Marai IFM, Kamal TH (1992) Heat Stress. In: Phillips, C., Pigginns, D. (Eds.), Farm Animals and the Environment. CAB International, Wallingford, UK, pp. 27-47.

Habeeb AAM, Atta MAA, EL-Tarabany A.A., Gad AE (2017) Improving live and dry body weight gain of bovine native calves during hot summer season of Egypt using genetic crossing Process. Journal of Animal Husbandry and Dairy Science 1:28-37.

Hooda OK, Singh S (2010) Effect of thermal stress on feed intake, plasma enzymes and blood biochemical in buffalo heifers. Indian Journal Animal Nutrition 27:122-127.

Kadzere CT, Murphy MR, Silanikove N, Maltz E (2002) Heat stress in lactating dairy cows: A review. Livestock Production Science 77:59-91

Kamal TH (1982) Water turnover rate and total body water as affected by different physiological factors under Egyptian environmental conditions. In: Use of tritiated water in studies of production and adaptation in ruminants. Proc., Res. Co-ord. Mtg., Organized by joint FAO/IAEA division Nairobi, Kenya, IAEA Panel Proc, Series, IAEA, Vienna:143-154.

Kamal TH, Habeeb AAM (1984) Comparison between methods of estimating total body water using tritiated water, Antipyrine and desiccation in Friesian cattle. Proc. of $1^{\text {st }}$ Egyptian-British Conf. on Animal and Poultry Production, Zagazig University, Zagazig , Egypt, 2:304-311.

Kamal TH and Habeeb AA (1999) The effect of sex difference in Friesian calves on heat tolerance using the heat-induced changes in total body water, total body solids and some blood components. Egyptian Journal Applied Science 14:1-15.

Kamal TH, Johnson H D (1971) Total body solids as measure of a short-term heat stress in cattle. Journal Animal Science 32:306-311.

Kamal TH, Seif SM (1969) Effect of natural and controlled climates of the sahra in virtual tritium in Friesians and water buffaloes. Journal Dairy Science 52:1657-1663.

Kamal TH, Mehrez AZ, El-Shinnawy MM, Abdel-Samee AM (1984) Estimation of evaporative water loss in mild and hot climates with use of tritiated water dilution technique in cattle. Proc. of $1^{\text {st }}$ EgyptianBritish Conf. on Animal and Poultry Production, Zagazig University, Zagazig, Egypt, 2:8-14.

Kamal TH, Kotby S, El-Fouly HA (1972) Total body solids gain and thyroid activity as influenced by goitrogen, diuretics, sprinkling and air cooling in heat stressed water buffaloes and Friesian. FAO/IAEA Symposium on Isotope Studies on the physiology of Domestic Animals, Athens, Greece, March 20-24,. Proc. Series, IAEA, Vienna, pp. 177-185.
Kendall PE, Webster JR (2009) Season and physiological status affects the circadian body temperature rhythm of dairy cows. Livestock Science 125:155-160.

Marai IFM, Habeeb AAM (2010a) Review: Buffaloes reproductive and productive traits as affected by heat stress. Tropical and Subtropical Agroecosystems 12:193-217.

Marai IFM, Habeeb AAM (2010b) Review article: Buffalo's biological functions as affected by heat stress - A review. Livestock Science 127:89-109.

Molee A, Bundasak B, Petladda K, Plern M (2011) Suitable percentage of Holstein incrossbred dairy cattle in climate change situation. Journal of Animal Husbandry and Dairy Science 10:828-831.

Mostageer A, Morsy MA, Nigm AA, Rashad NS, Pirchner F (1990) Milk production characteristics of Baladi cattle and their F1 crossbreds with some European breeds. Journal of Animal Breeding and Genetics 107:301-310.

Norris D, Macala J, Makore J, Mosimanyana B (2002) Feedlot performance of various breed groups of cattle fed low to high levels of roughage. Livestock Research for Rural Development 14:6-11.

Olson TA (2011) Crossbreeding Programs for Beef Cattle in Florida Publication. University of Florida, IFAS Extension, BUL, 326

Pastsart U, Piyopummintr A, Kanjanapruthipong J, Siripholvat V (2006) Heat shock protein 90 (Hsp90) Gene polymorphism associated with heat tolerance traits in crossbred dairy cattle and their native cattle. Agriculture Science Journal 37:393-398.

Rhoads RP, Baumgard LH, Suagee JK, Sanders SR (2013) Nutritional interventions to alleviate the negative consequences of heat stress. Advanced Nutrition 4:267-276.

SAS (2002) Institute. SAS/STAT User's Guide: Version 8.2. SAS Institute Inc., Cary, NC.

Shwartz G, Rhoads ML, Van Baale MJ, Rhoads PP, Baumgard LH (2009) Effects of a supplemental yeast culture on heat-stressed lactating Holstein cows. Journal of Dairy Science 92:935-942.

Yasothai R (2014) Effect of climate on nutrient intake and metabolism and countered heat stress by nutritional manipulation. International Journal of Science, Environment and Technology 3:1685-1690. 